\title{
Evaluation of Stress Intensity Factor using Displacement Correlation Techniques
}

\author{
Abdulnaser M. Alshoaibi and Ahmad Kamal Ariffin
}

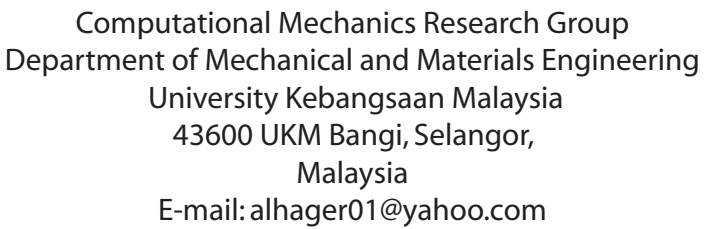

\begin{abstract}
The simulation of crack propagation relies on accurate computing of stress intensity factors (SIFs) at crack tips. Numerical methods are used to calculate the crack propagation path based on the computation of the crack incremental direction and stress intensity factors $K_{I^{\prime}} K_{I I}$ from the finite element response. This paper evaluates a nodal displacement method used for prediction of stress intensity factors. The method evaluated is the displacement correlation technique (DCT).The DCT is used when the singular element is present at the crack tip, and it uses the differential displacements for the adjacent nodes across the crack to compute the stress intensity factors. The crack path and its stress intensity factors are calculated in a specialised finite element program, using small crack increments. At each crack propagation step, the mesh is automatically refined based on automatic adaptive strategy that takes into account the estimation of stress analysis in two-dimension elastoplastic fracture. Crack has been modelled to propagate through the inter-element in the mesh. The crack is free to propagates without predetermine path direction. Maximum principal normal stress criterion is used as the direction criterion.
\end{abstract}

Keywords: Finite Element, displacement correlation technique, stress intensity factor, crack propagation

\section{ABSTRAK}

Kejituan dalam pengiraan faktor-faktor penumpuan tegasan (SIFs) adalah salah satu aspek penting dalam simulasi rambatan retak. Arah rambatan dan faktor-faktor penumpuan tegasan $K_{I}, K_{I I}$ ditentukan berdasarkan penyelesaian berangka kaedah unsur terhingga. Makalah ini membentangkan penentuan SIFs mengikut salah satu kaedah sesaran titik iaitu teknik kolerasi sesaran (DCT). Teknik ini digunakan apabila terdapat unsur-unsur singular pada titik retak. SIFs dikira melalui perbezaan sesaran-sesaran yang berlaku pada titiktitik yang bersebelahan dengan titik retak dengan manipulasi tertentu. Pengiraan menggunapakai kaedah unsur terhingga adaptif di mana proses penghalusan jejaring adalah secara automatik menggunakan penganggar posteriori ralat tegasan norma. Alur keretakan dimodelkan sekira merambat antara unsur-unsur 
jejaring secara bebas, tanpa sebarang arah yang dipra-tentu. Kriteria yang digunakan dalam penentuan arah rambatan adalah kriteria tegasan normal utama maksimum.

Kata kunci: Unsur terhingga, teknik kolerasi sesaran, faktor penumpuan tegasan, perambatan retak.

\section{INTRODUCTION}

The finite element method has been largely used to analyze mechanical problems in particular, to obtain the response of cracked structures. The main aim of fracture investigations is the ability to predict the size of crack. This crack will propagate under a given loading in a given material from measurements of the size of crack, which propagates under another loading in the same material. The relationship between these sizes is dependent on the conditions near the tip of the crack, where non-elastic are significant. However, provided that such a region is small compared with the crack dimensions, a linear elastic field may be assumed around the crack tip. In these circumstances, the onset of the fracture is controlled by the magnitude of stress intensity factors $K_{l}, K_{l I^{\prime}}$ and $K_{1 / I^{\prime}}$ Plane tensile mode is applied in mode I, where the crack surface is symmetrically opened. As for shear mode II, represented a skew-symmetric in-plane loading. Mode III occurs when the crack surface is twisted by forces perpendicular to the crack plane as illustrated in Figure 1. The accurate numerical computation of stress intensity factor is a key factor to a successful application of linear for calculating the stress intensity factors such as the Quarter Point Displacement technique, the Displacement Extrapolation technique, and the Displacement Interpretation method. This paper is an evaluation of one of these techniques, which is the displacement correlation technique (DCT). The stress intensity factor, $K$, was initially used to quantify crack-tip damage for fracture scenarios. Fracture occurs when the crack-tip stress intensity factor reached a critical value, $K_{C^{\prime}}$ independent of crack size or net applied stress (Irwin 1957).This observation lead to the concept of crack similitude, i.e. cracks of different length will fracture at the same $K_{C}$

Gray et al. (2003) presented a modification to the quarter-point crack tip element and employ this element in two-dimensional boundary integral fracture analysis. The stress intensity factor was calculated by using the displacement correlation technique, which was highly accurate, and significantly more accurate than with the standard element. Phongthanapanich and Dechaumphai (2004) used a finite element method, with the adaptive Delaunay triangulation as mesh generator to analyse two-dimensional crack propagation problems. They described the

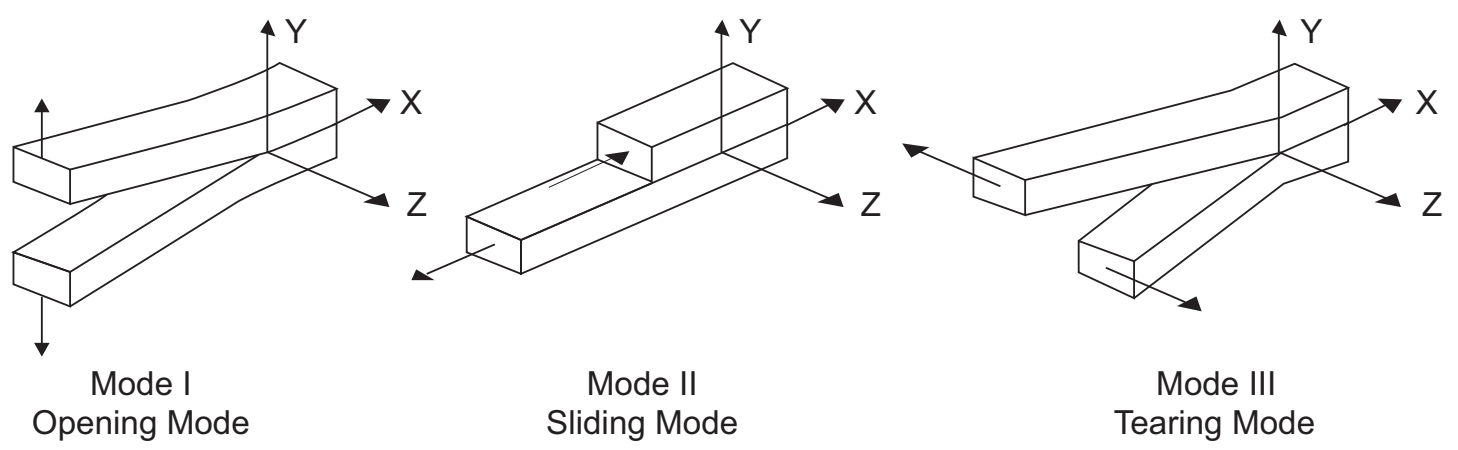

FIGURE 1. Types of stress intensity factors.

elastic fracture mechanics concept. Fracture mechanics as we know it today began nearly 47 years ago when Irwin (1957) developed the concept of the stress intensity factor. Since until now, researchers continue to investigate and develop tools that will provide accurate assessment of cracking in structures. These tools include nodal displacement techniques
Delaunay triangulation procedure consisting of mesh generation, node creation, mesh smoothing, and adaptive remeshing, all with object-oriented programming. They also used the displacement extrapolation method to determine the values of stress intensity factors. Rao and Rahman (2001) developed a coupled meshless-finite element method to analysing linear-elastic cracked 
structures which were subjected to mode I and mixed mode condition. The proposed method was applied to calculate mode I and mode II stress intensity factors in a many types of twodimensional cracked structures.

The purpose of this paper is to evaluate the stress intensity factors by using the displacement correlation technique. This method requires only a few nodal displacements around the crack tip. A computer code is developed using Fortran programming language for finite element analysis calculation processes, which is based on displacement control loading. The developed program consists of three processes i.e. nonlinearity in geometry, material and boundary conditions.

\section{SIMULATION OF CRACK PROPAGATION}

There are several methods to predict the direction of crack propagation such as the maximum circumferential stress theory (Erdogan \& Sih 1963), the maximum energy release rate theory (Nuismer 1975), and the minimum strain energy density theory (Sih 1974).In the maximum circumferential stress theory, the direction of crack propagation $\theta$ is computed from:

$$
K_{,} \sin \theta+K_{I I}(3 \cos \theta-1)=0
$$

which was used in the present paper to predict
(Akisanya \& Fleck 1992; Geubelle \& Knauss 1994; Hutchinson \& Suo1992).

Based on Eq.(1) analysis, it is found that for pure mode I that $K_{\| I}=0, K_{l} \sin \theta=0$ and $\theta=0^{\circ}$. As far for pure mode $I I, K=0$, and $\theta= \pm 0.75^{\circ}$. This values of $\theta$ are the extreme values of the crack propagation angles. The intermediary values are found by solving Eq. (1) by considering the mixed mode, which result:

$$
\theta=2 \arctan \left(\frac{1}{4} \frac{K_{I}}{K_{I I}} \pm \frac{1}{4} \sqrt{\left(\frac{K_{I}}{K_{I I}}\right)^{2}}+8\right)
$$

\section{DISPLACEMENT CORRELATION TECHNIQUE}

The DCT uses all four nodes on the crack faces, as shown in Figure 2. The technique uses the differential displacements of the adjacent nodes across the crack to compute the stress intensity factors as:

$$
\begin{aligned}
& K_{l}=\frac{G}{\kappa+1} \sqrt{\frac{2 \pi}{L}}\left[4\left(v_{1}-v_{2}\right)-\left(v_{3}-v_{4}\right)\right] \\
& K_{I I}=\frac{G}{\kappa+1} \sqrt{\frac{2 \pi}{L}}\left[4\left(u_{1}-u_{2}\right)-\left(u_{3}-u_{4}\right)\right]
\end{aligned}
$$

where $G$ is the shear modulus, $\kappa=(3-4 v)$ for

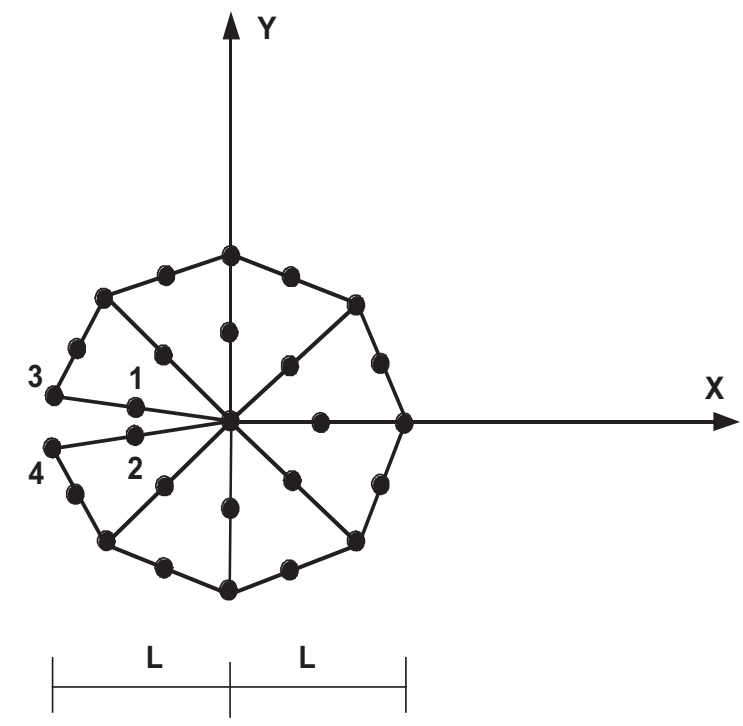

FIGURE 2. Displacement correlation technique uses nodes $1,2,3$ and 4

the crack propagation direction. Although the three criteria specify different aspects, they all yield similar results and no experimentally distinguishable differences have been observed plane strain, $\kappa=(3-v) /(1+v)$ for plane stress, $L$ is the length of the singular element, $v$ is the Poisson's ratio, $u_{i}$ is the lateral displacement with respect to crack direction for the $i$ th node and $v_{i}$ 
is the transverse displacement with respect to crack direction for the $i$ th node.

Figure 3 describes the flow-chart for stress intensity factors evaluation and crack propagation trajectory prediction using adaptive meshing technique. The combined adaptive meshing technique and the crack propagation analysis according to the figure can be described in the following steps:

1) Create geometry model with initial crack which is define by the users.

2) Discretise the domain into triangular elements.
Then apply the boundary conditions into finite element model.

3) Solve the system of finite element equations for displacement solutions. Then compute the stress intensity factors using Eqs. (3 and 4).

4) If the crack tip has reached the final target position, then stop the process. Otherwise determine the crack direction, delete the old mesh, generate a new adaptive mesh, and update the model with the new crack geometry.

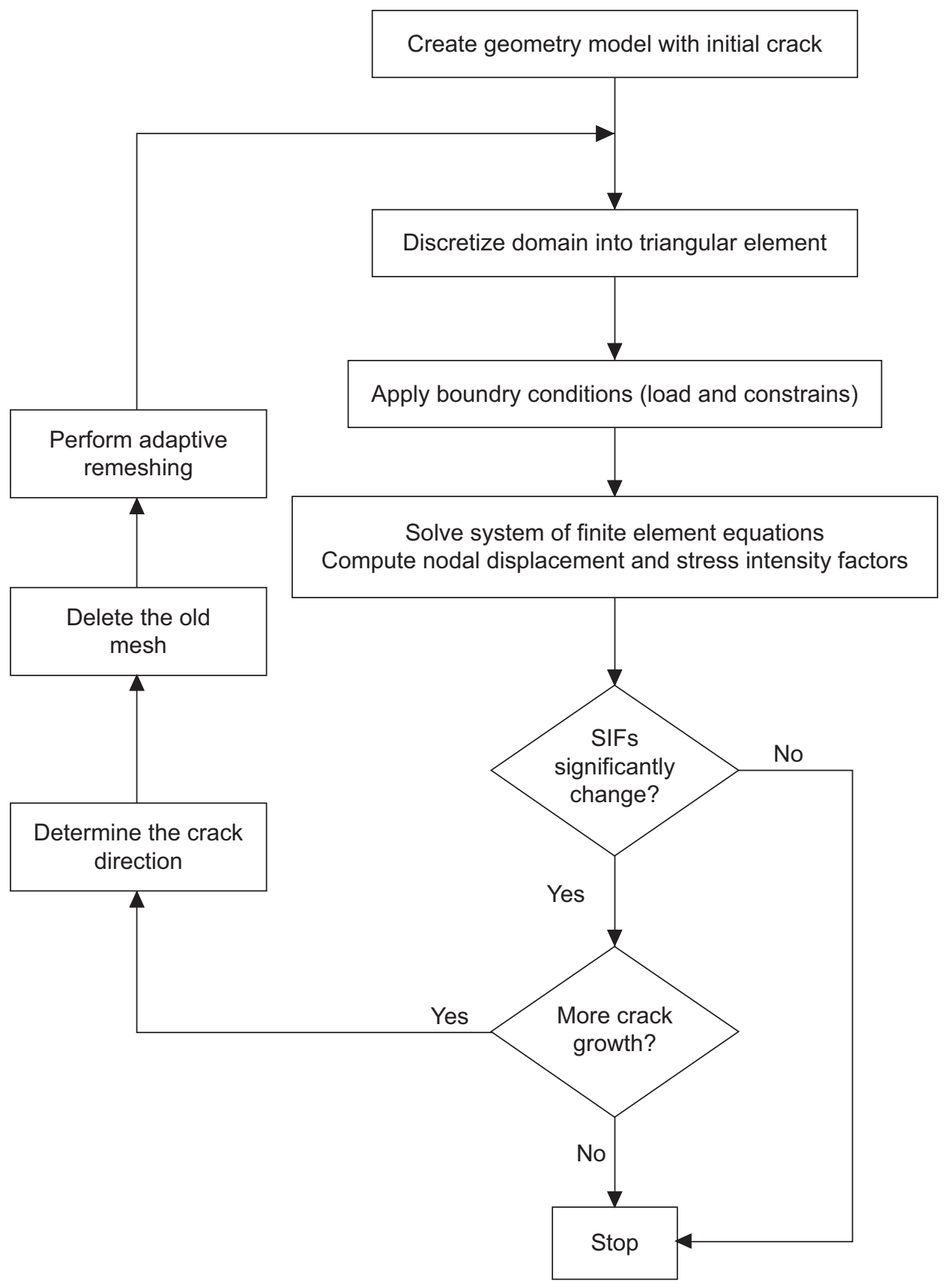

FIGURE 3. Flowchart of SIFs evaluation and crack trajectory prediction. 


\section{NUMERICAL ANALYSIS}

The method developed in this study was applied to perform fracture mechanics analysis of stationary cracks under pure tension (mode I).

\section{A Single Edge Crack with Square Geometry}

Figure 4 shows the problem statement and the final mesh of a single edge cracked plate under uniaxial tension loading. The employed finite element program was an adaptive mesh strategy to simulate the crack propagation in two-dimension condition. The dimensions of the plate are the width $W=50 \mathrm{~mm}$, the height $h=50 \mathrm{~mm}$, and the crack length $a=25 \mathrm{~mm}$.

The modulus of elasticity and Poisson's ratio are $210 \mathrm{GPa}$ and 0.3 respectively. The applied uniaxial tensile load is $200 \mathrm{MPa}$, which is the same load applied by Zuh and Smith (1995), and the equivalent displacements of this load are shown in Table 1.Zhu and Smith(1995) presented four methods to determine $K$, using the Displacement Extrapolation method. The results of these four methods are compared to the results obtained by Banks-Sills and Sherman (1986), and Isida (1971) as shown in Table 2.

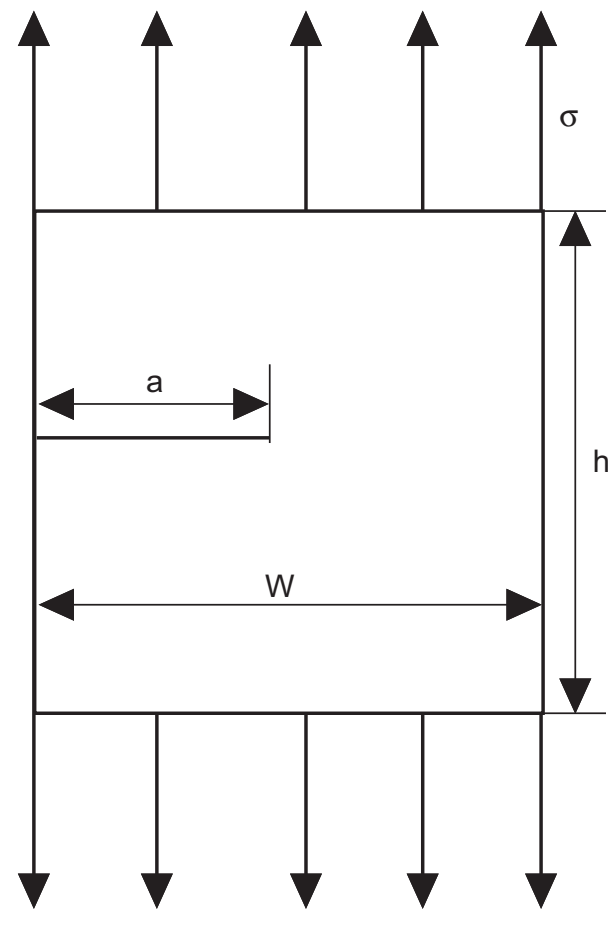

(a)

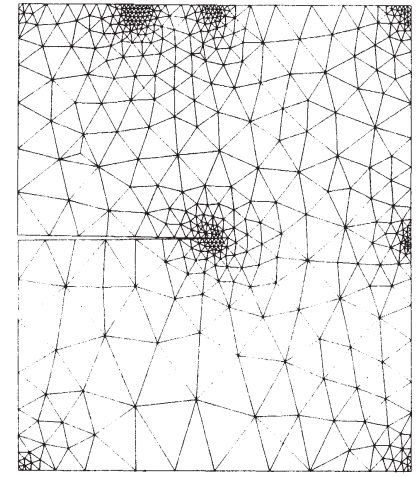

(b)

FIGURE 4. (a) Problem statement and (b) the final mesh of the initial crack for single edge crack with square plate

TABLE 1. Equivalent nodal displacement of the uniaxial tension load of $200 \mathrm{Mpa}$

\begin{tabular}{ccc}
\hline$(\mathbf{X}, \mathbf{Y})$ coordinate & $\mathbf{U}_{\mathbf{X}}(\mathbf{m})$ & $\mathbf{V}_{\mathbf{Y}}(\mathbf{m})$ \\
\hline$(0,05)$ & $1.33572 \times 10^{-4}$ & $1.20092 \times 10^{-4}$ \\
$(0.03,0.05)$ & $1.252018 \times 10^{-4}$ & $4.887042 \times 10^{-5}$ \\
$(0.04,0.05)$ & $1.223499 \times 10^{-4}$ & $2.29889 \times 10^{-5}$ \\
$(0.05,0.05)$ & $1.20092 \times 10^{-4}$ & $-3.208217 \times 10^{-6}$ \\
\hline
\end{tabular}

TABLE 2. Non-dimensionalized results of $K$, for a single edge crack plate (Zhu and Smith(1995))

\begin{tabular}{cccccccc}
\hline $\boldsymbol{K}_{\text {loy }}$ & $\%$ & $\boldsymbol{K}_{\text {lox }}$ & $\%$ & $\boldsymbol{K}_{\text {luy }}$ & $\%$ & $\boldsymbol{K}_{\text {lux }}$ & $\%$ \\
\hline 2.8107 & -0.23 & 2.8006 & -0.62 & 2.817 & -0.04 & 2.7931 & -0.88 \\
\hline
\end{tabular}


$\sigma$

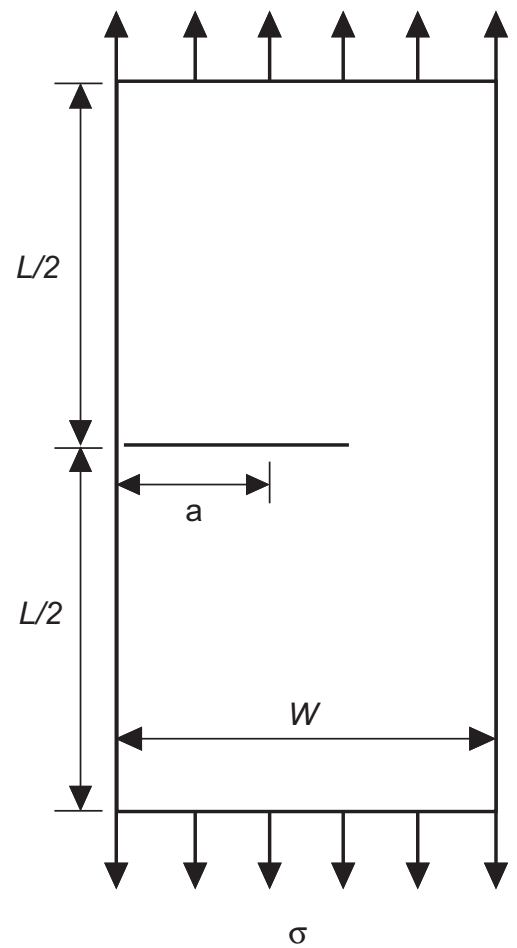

(a)

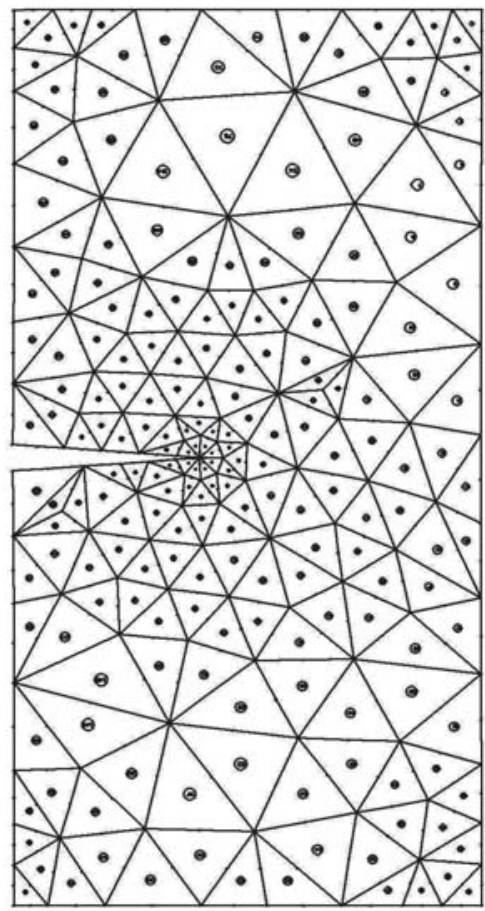

(b)

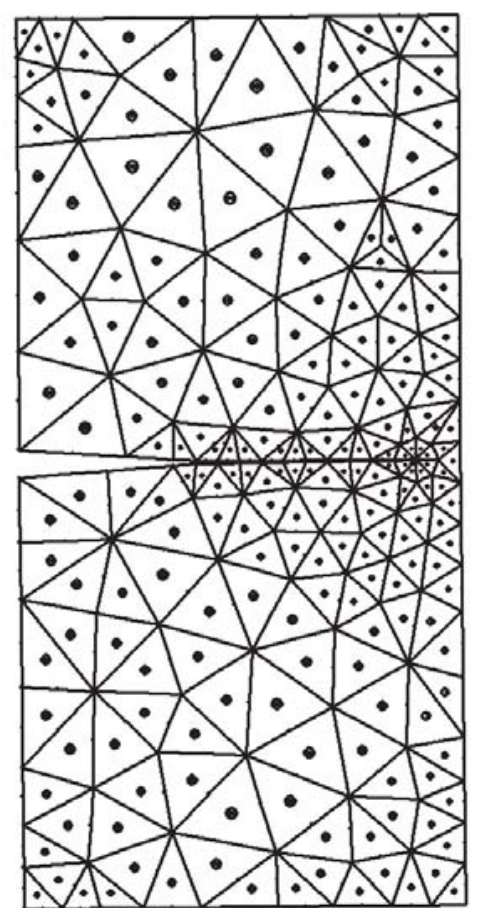

(c)

FIGURE 5. (a) Problem statement, (b) the final mesh of the initial crack and (c) the final mesh of the crack in the final step of propagation

In the present study the value of $K$, as calculated by the displacement correlation technique is 2.81665 , which is in agreement with previous works by Zhu and Smith (1995) and with their reference value 2.818 .

\section{A Single Edge Crack With Rectangular Geometry}

An edge-cracked plate under pure tension as shown in Figure 5, that has length, $L=2$ units, width, $W=1$ unit, and crack length, $a=0.4$ units is considered. The far-field tensile stress, $\sigma$ is taken as 1 units.

The stress intensity factor of 2.357 was calculated from Tada et al. (2000) as:

$$
K_{l}=F \sigma \sqrt{\pi a}
$$

Where,

$F=1.12-0.231 \alpha+10.55 \alpha^{2}-21.72 \alpha^{3}+30.39 \alpha^{4}$ and $\alpha=\frac{a}{w}$.

Phongthanapanich and Dechaumphai (2004) computed the value of stress intensity factor for this geometry using finite element method, with adaptive Delaunay triangulation as mesh generation to be 2.358. Rao and Rahman (2000) proposed an efficient meshless method for fracture analysis of cracks. The values of stress intensity factor for pure mode I were estimated for the similar geometry and boundary condition in the present study as shown in Table 3.

Using the Displacement Correlation Technique the calculated value of stress intensity factor is

TABLE 3. $K_{1}$ using enriched basis functions obtained by Rao and Rahman (2000)

\begin{tabular}{cc}
\hline Type of enrichment & $\boldsymbol{K}_{\boldsymbol{I}}$ \\
\hline Full & 2.366 \\
Radial & 2.360 \\
Hybrid & 2.337 \\
\hline
\end{tabular}


2.354, which shows an excellent agreement with Tada et al. (2000).

Using the developed displacement correlation technique, $K$, can be simply obtained from a few nodal displacements which gives similar results as in the displacement extrapolation techniques (Zhu \& Smith 1995). The essential prerequisite of the developed method in this paper is that finite element analysis provides accurate displacement. Moreover, it can be used to obtain nodal displacements with sufficient accuracy either for more general or mixed mode crack problems.

\section{REFERENCES}

Akisanya, A.R. \& Fleck, N.A.1992. Brittle fracture of adhesive joints. International Journal of Fracture 58: 93-114.

Banks-Sills, L. \& Sherman, D. 1986. Comparison of method for calculating stress intensity factor with quarter-point elements. International Journal of Fracture Mechanics 32: 127-140.

Erdogan, F.\& Sih,G.C.1963. On the crack extension in plates under plane loading and transverse shear. Journal of Basic Engineering 85:519-527.

Geubelle, P.H.\& Knauss, W.G. 1994. Crack propagation at and near bimaterial interfaces: linear analysis. Journal of Applied Mechanics 61:560-566.

Gray, L.J., Phan, A.V., Paulino, G.H. \& Kaplan, T. 2003. Improved quarter-point crack tip element. Engineering Fracture Mechanics 70: 269-283.

Hutchinson, J.W. \& Suo, Z. 1992. Mixed mode cracking in layered materials. Advances in Applied Mechanics 29:63-191.

Irwin, G.R. 1957. Analysis of stresses and strains near the end of a crack traversing a plate. Journal of Applied Mechanics 24:361-364.

Isida, M. 1971. Effect of width and length on stress intensity factors of internally cracked plates under various boundary conditions.International

\section{CONCLUSION}

A finite element program is developed to determine the stress intensity factor using the displacement correlation. The major benefit of this technique is that no analytical solutions are required. Finite element analysis with nodal displacement technique proves to give similar values of $K$, to those found in other methods. Finally crack propagation directions can be predicted by the maximum normal stress criterion.

Journal of Fracture 7: 301-316.

Nuismer,R.J. 1975. An energy release rate criterion for mixed mode fracture. International. Journal of Fracture 11(2): 245-250.

Phongthanapanich, S. \& Dechaumphai, P. 2004. Adaptive delaunay triangulation with objectoriented programming for crack propagation analysis. Finite Element in Analysis and Design 40:1753-1771.

Rao, B.N. \& Rahman, S. 2000. An efficient meshless method for fracture analysis of cracks. Computational Mechanics 60:398-408.

Rao, B.N.\& Rahman,S.2001. A coupled meshless-finite element method for fracture analysis of cracks. International Journal of Pressure Vessels and Piping 78: 647-657.

Sih, G.C. 1974. Strain-energy-density factor applied to mixed-mode crack problems. International. Journal of Fracture 10: 305-321.

Tada, H., Paris, P.C. \& Irwin, G.R. 2000. The Stress Analysis of Cracks Handbook. ASME Press: New York.

Zhu,W.X.\& Smith, D.J.1995. On the use of displacement extrapolation to obtain crack tip singular stresses and stress intensity factors. Engineering Fracture Mechanics 51(3):391-400. 